\title{
INNOWACYJNOŚĆ, PRODUKTYWNOŚĆ I KONKURENCYJNOŚĆ GOSPODARKI A MIĘDZYNARODOWA WSPÓŁPRACA GOSPODARCZA*
}

Głównym celem opracowania jest identyfikacja oraz dokonanie przeglądu i oceny możliwych związków pomiędzy innowacyjnością i konkurencyjnościa gospodarki a międzynarodową współpracą gospodarczą. Podporządkowana temu jest realizacja czterech celów szczegółowych. Pierwszym celem jest identyfikacja i zewidencjonowanie możliwych kanałów obustronnego wpływu pomiędzy badanymi zmiennymi. Drugim celem jest zakwalifikowanie poszczególnych kanałów wpływu do różnych występujących w literaturze koncepcji teoretycznych. Wreszcie trzeci cel to dokonanie przeglądu wyników badań empirycznych dotyczących związków innowacyjności, konkurencyjności i międzynarodowej współpracy gospodarczej wraz z ich odniesieniem do wątków występujacych w literaturze przedmiotu. Czwartym celem będzie zarysowanie implikacji praktycznych przeprowadzonych rozważań, czyli rekomendacji dla polityki gospodarczej.

\section{ZALOŻENIA WSTĘPNE}

Niżej opisane rozumowanie odnosi się do gospodarki rynkowej prowadzącej współpracę gospodarczą z zagranica. Chodzi o gospodarkę otwartą zarówno wpływajacca na swoje otoczenie zagraniczne, jak i podlegająca wpływom tegoż otoczenia. Natomiast jeśli chodzi o kierunek wpływu, to zdając sobie sprawę z jego dwustronności, uwaga zogniskowana jest jednak na wpływie otoczenia zagranicznego na tę gospodarkę. Gospodarka narodowa jako całość jest więc podstawową jednostką analizy, choć zasadne będzie wyjście od podstaw mikroekonomicznych badanych związków.

Cała gospodarka narodowa składa się z podsystemów niższego rzędu, jakie z jednej strony stanowią poszczególne branże albo sektory gospodarki, a z drugiej - składnikami gospodarki narodowej są gospodarki poszczególnych regionów/województw. Przyjmując założenie hierarchicznej budowy systemu gospodarczego, należy jeszcze zaznaczyć, że poszczególne sektory/branże gospodarki składają się z elementów niższego rzędu, jakie stanowią przedsiębiorstwa.

" Autor dziękuje prof. Ewie Mińskiej-Struzik i prof. Marzennie Weresie za konsultacje udzielone przy powstawaniu tego tekstu. 
W ramach założeń wstępnych warto jest także zdefiniować triadę istotnych z rozważanego punktu widzenia pojęć: innowacyjność, produktywnośćl wydajność i konkurencyjność. Sa to pojęcia ściśle z sobą powiązane, choć nie zawsze jednolicie definiowane. Zależności między nimi można ująć w uproszczonym schemacie analitycznym (schemat 1$)$.

\section{Schemat 1}

Triada pojęć: innowacyjność, produktywność/wydajność, konkurencyjność a międzynarodowa współpraca gospodarcza

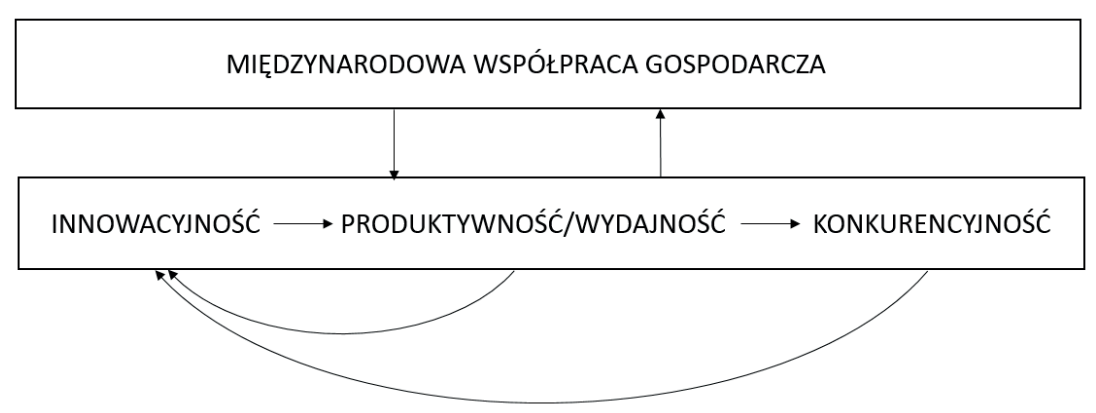

Źródło: opracowanie własne.

Innowacyjność oznacza zdolność do wprowadzania innowacji ${ }^{1}$. Standardowo przyjmuje się, że wprowadzanie innowacji dyktowane jest dążeniem do osiagania zysków. Innowacje ${ }^{2}$ są nośnikiem postępu technicznego, który przyczynia się do zwiększenia produktywności/wydajności czynników produkcji rozumianej jako relacja efektów do nakładów. Postęp techniczny jest jednym z czynników wpływających na podwyższenie produktywności/wydajności. Inne czynniki to learning by doing, uczenie się od innych, zmiany organizacyjne, zmiany systemowe (prawne, regulacyjne) $)^{3}$. Z kolei wyższa produktywność przyczynia się do poprawy konkurencyjności rozumianej jako umiejętność

${ }^{1} \mathrm{~W}$ uproszczeniu innowacje obejmują nowe produkty, nowe procesy, nowe metody marketingu oraz nowe sposoby organizacji działalności gospodarczej - Innowacje, w: Stownik Innowacji - Leksykon Haset, <http://www.pi.gov.pl/parp/chapter_96055.asp?soid=677964766D394262AB915FB61187C008> [dostęp: 15.06.2018]. Ponadto wyróżnia się jeszcze innowacje instytucjonalne i społeczne, które nie mają technologicznego charakteru. Zob. także Oslo Manual. Guide for Collecting and Interpreting Technological Innovation Data, OECD, Paris 2005; M.E. Porter, The Competitive Advantage of Nations, London 1990; J.A. Schumpeter, Teoria rozwoju gospodarczego, Warszawa 1960.

2 Atrybut ten przysługuje innowacjom technologicznym, do których zalicza się innowacje produktowe i procesowe. W dalszej części tekstu uwaga zostanie skupiona na tych dwóch rodzajach innowacji.

${ }^{3}$ L. Wojciechowski, Napływ zagranicznych inwestycji bezpośrednich a produktywność gospodarek krajów Grupy Wyszechradzkiej, praca doktorska niepublikowana, Kraków 2018, s. 101-102. 
działania i przetrwania w konkurencyjnym otoczeniu, czego wskaźnikami sa udział w rynku i zyskowność prowadzonej działalności ${ }^{4}$.

Warto wreszcie podkreślić, że zależność pomiędzy rozważaną triadą a międzynarodową współpraca gospodarczą ma charakter dwustronny. Z jednej strony sam fakt prowadzenia szeroko rozumianej wymiany międzynarodowej na różne sposoby może przyczyniać się do poprawy każdego z elementów triady. Z drugiej strony zmiany innowacyjności, produktywności i konkurencyjności wpływają na międzynarodową współpracę gospodarczą. Wpływ ten może być różnoraki, zazwyczaj jednak poprawa w ramach elementów triady prowadzi do stymulowania kooperacji międzynarodowej oraz umożliwia odnoszenie z niej większych korzyści. W tym opracowaniu eksponowany jest wpływ współpracy z zagranica na elementy triady.

\section{KANAEY WPEYWU: \\ TRIADA A WSPÓŁPRACA GOSPODARCZA Z ZAGRANICA - MAPA MOŻLIWOŚCI}

Biorąc pod uwagę dyskusję tocząca się we współczesnej ekonomii odnośnie do powiązań pomiędzy makroekonomią a mikroekonomia, wydaje się, że dla zbadania zasygnalizowanego zagadnienia za punkt wyjścia wskazane jest przyjąć określone podstawy mikroekonomiczne. U podstaw takiego rozumowania tkwi przekonanie, że innowacyjność, produktywność i konkurencyjność na poziomach wyższych od szczebla mikro są agregatami, wypadkowymi sytuacji na poziomie mikro. Uzasadnione jest więc pokazanie, w jaki sposób współpraca gospodarcza z zagranicą może, po pierwsze, przyczyniać się do podniesienia innowacyjności, produktywności i konkurencyjności na poziomie mikroekonomicznym oraz jak te ostatnie mogą wpływać na sytuację makroekonomiczna.

W punkcie wyjścia uwaga zostanie zogniskowana - zgodnie z przyjętym na początku założeniem - na wpływie otoczenia zagranicznego na gospodarkę polska, co w przełożeniu na język ekonomiczny sprowadza się do konsekwencji prowadzenia współpracy z podmiotami zagranicznymi dla podmiotów krajowych.

Przyjmując wyżej zasygnalizowaną koncepcję rozumowania, na początku należy zaznaczyć, że kanały wpływu współpracy z zagranicą na konkurencyjność przedsiębiorstw powinny uwzględniać wszystkie możliwe formy współpracy gospodarczej firm krajowych z podmiotami zagranicznymi. Formy te można uporządkować następująco ${ }^{5}$ :

Eksport/import

- pośredni

- bezpośredni;

${ }^{4}$ M. Gorynia, Teoretyczne aspekty konkurencyjności, w: idem, E. Łaźniewska (red.), Kompendium wiedzy o konkurencyjności, Warszawa 2009, s. 50.

${ }^{5}$ M. Gorynia, Strategie zagranicznej ekspansji przedsiębiorstw, Warszawa 2007, s. 109-110. 
Kooperacja

- Kooperacja niekapitałowa

- kontrakty licencyjne

- umowy franczyzowe

- kontrakty na zarządzanie (management contracts)

- inwestycje „pod klucz”

- poddostawy (subcontracting)

- konsorcja

- Kooperacja kapitałowa

- Sojusze strategiczne;

Samodzielna działalność na rynkach zagranicznych.

Wymienione formy współpracy firm polskich z firmami zagranicznymi moga dotyczyć zarówno sytuacji, gdy firma jest biorca (strona pasywna) - internacjonalizacja pasywna, jak i dawca (strona aktywna) - internacjonalizacja czynna. W ramach internacjonalizacji pasywnej wpływ zagranicy na innowacyjność i konkurencyjność firm krajowych występuje wtedy, gdy firmy zagraniczne dostarczają firmom polskim towary i usługi nasycone innowacjami. Pierwsza formą współpracy jest import. W wypadku zakupu za granicą nowoczesnych maszyn i urządzeń stan innowacyjności i konkurencyjności gospodarki krajowej powinien się z definicji podnosić. Samym zakupom inwestycyjnym towarzysza często kontrakty licencyjne, upoważniajace nabywcę do odpłatnego korzystania z technologii wytworzonych przez inne podmioty. Klasyczny kontrakt licencyjny, obejmujacy sprzedaż licencji, może być rozwinięty o inne świadczenia ze strony licencjodawcy na rzecz licencjobiorcy, takie jak szkolenie personelu licencjobiorcy, nadzór nad wdrożeniem produkcyjnym, nadzór nad komercjalizacja, kontrakt na zarządzanie, dostawy inwestycyjne, dostawy kooperacyjne, dystrybucja i sprzedaż wyrobu licencjonowanego oraz inwestycje odtworzeniowe i modernizacyjne. Podobny charakter moga mieć kontrakty franczyzowe, przewidujące możliwość wykorzystywania przez franczyzobiorcę formuły prowadzenia biznesu opracowanej przez franczyzodawcę. Także te kontrakty mogą być nasycone fachową wiedzą przydatną w prowadzeniu działalności gospodarczej, przyczyniającą się do podniesienia poziomu innowacyjności i konkurencyjności.

Kolejną wartą uwagi formą sa kontrakty menedżerskie zawieranie pomiędzy firmami krajowymi a zagranicznymi. Oznaczają one import usług zarządzania świadczonych przez firmy zagraniczne. W czystej postaci kontrakty te nie sa związane z przepływem dóbr materialnych, polegają natomiast na transferze zaawansowanej wiedzy menedżerskiej. Dodatkowo mogą być obudowywane innymi rodzajami świadczeń na rzecz firmy zarządzanej.

Bardziej skomplikowany charakter moga mieć kontrakty inwestycyjne „pod klucz”. Ich istota wiąże się z dostawą kompleksowego przedmiotu kontraktu - kompletnego obiektu przemysłowego, który standardowo stanowi mieszankę dóbr materialnych i wiedzy potrzebnej do ich eksploatacji. Moga one być także rozwijane do wersji product-in-hand (gdzie sprzedajacy odpowiada również za wdrożenie procesów produkcyjnych u nabywcy) oraz marketin-hand (gdzie sprzedajacy przejmuje na siebie zobowiązanie wprowadzenia 
produktu na rynek). Również kontrakty na poddostawy realizowane przez podmiot zagraniczny moga przyczyniać się do podniesienia stopnia innowacyjności i konkurencyjności firmy - np. można sobie wyobrazić sytuację, że bez określonych zaawansowanych podzespołów nie jest możliwa produkcja wyrobu wysokiej techniki. Konsorcja, joint ventures (kooperacja kapitałowa) oraz sojusze strategiczne to formy współpracy, gdzie zazwyczaj przepływom materialnym towarzyszą transfery wiedzy pomiędzy uczestnikami porozumień. Takie porozumienia mogą także mieć duży potencjał wpływu na innowacyjność i konkurencyjność podmiotów.

Ostatnią rozpatrywaną formą współpracy gospodarczej z zagranicą mogąca powodować konsekwencje w sferze innowacyjności i konkurencyjności jest prowadzenie samodzielnej działalności na rynku zagranicznym przyjmujace najczęściej formę filii własnej albo oddziału, które powoływane są do wykonywania działalności produkcyjnej i/lub usługowej na rynku docelowym. W tym wypadku chodzi o obecność podmiotów zagranicznych na rynku polskim i o ich wpływ na poziom nowoczesności i konkurencyjności podmiotów prowadzących działalność na tymże rynku.

W dalszym kroku rozumowania możliwe jest uchylenie przyjętego na początku założenia o badaniu wyłącznie wpływu biernych form internacjonalizacji firmy na jej innowacyjność i konkurencyjność. Można postawić dalej idące pytanie: czy internacjonalizacja czynna może być także źródłem konsekwencji sprowadzających się do wzrostu innowacyjności i konkurencyjności dokonującej jej firmy? Odpowiedź na to pytanie nie jest tak oczywista i prosta, jak w wypadku internacjonalizacji biernej. Wydaje się jednak wstępnie, że praktycznie każda forma zagranicznej ekspansji przedsiębiorstwa rozpatrywana z perspektywy firmy dokonującej internacjonalizacji czynnej może potencjalnie prowadzić do efektów w postaci wzrostu poziomu innowacyjności, produktywności i konkurencyjności. Do zaproponowania mechanizmu wyjaśniającego ten fenomen użyteczna może być koncepcja learning by exporting (uczenie się przez eksport) ${ }^{6}$. Zostanie ona szczegółowiej zaprezentowana w dalszej części opracowania.

Powyższe konstatacje stanowią podstawę do sformułowania następującego komentarza. Wydaje się, że realia mikroekonomiczne powinny być uwzględniane we wszystkich analizach empirycznych obrazujacych wpływ współpracy z zagranica na innowacyjność i konkurencyjność gospodarki. Można powiedzieć, że gospodarka narodowa jest suma, a nawet czymś więcej niż suma, wielkiej liczby case studies - przypadków poszczególnych przedsiębiorstw zaangażowanych we współpracę międzynarodową z uwzględnieniem dodatkowo efektów synergii pomiędzy działaniami poszczególnych firm. Nie jest to więc prosta suma pojedynczych przypadków. Bogactwo i złożoność powiązań na poziomie mikro znajdują jedynie powierzchowne odzwierciedlenie w uproszczonych statystykach na poziomie makro. Jeśli chodzi o statystyki eksportowo-importowe, to rejestruje się w nich import na bazie franco granica polska oraz eksport na bazie franco granica kraju odbiorcy z niezadowalajaco dokładnym ujęciem struktury produktowej. Jeśli natomiast chodzi o prze-

${ }^{6}$ E. Mińska-Struzik, Od eksportu do innowacji. Uczenie się przez eksport polskich przedsiębiorstw, Warszawa 2014. 
pływy zagranicznych inwestycji bezpośrednich (ZIB), to wypada zauważyć, że do przysłowiowego jednego worka wkłada się zarówno napływ środków na inwestycje greenfield, napływ środków w ramach przejęć i fuzji oraz dodatkowo reinwestowane w kraju goszczącym zyski. Oczywiste jest natomiast, że potencjał kreowania przyrostu innowacyjności, produktywności i konkurencyjności przez poszczególne kategorie środków napływających w ramach ZIB jest zróżnicowany i w efekcie struktura tych środków też ma znaczenie. Tymczasem większość makroekonomicznych teorii odnoszących się do współpracy gospodarczej z zagranicą odwołuje się do istniejących statystyk, które - jak zasygnalizowano - mają uproszczony charakter. Można więc zadać pytanie: w jakiej mierze uproszczone i nieadekwatne statystyki pozwalają na zasadne przetwarzanie danych, ich obróbkę, wnioskowanie i interpretację? Czy ze słabo ugruntowanych przesłanek można wyciagać właściwe wnioski?

\section{CO NA TO TEORIA? MAPA WYJAŚNIEŃ TEORETYCZNYCH}

W tej części opracowania zostanie podjęta próba dokonania przeglądu, jak funkcjonujące w literaturze teorie ujmują efekty współpracy gospodarczej z zagranica z punktu widzenia ich wpływu na innowacyjność, produktywność i konkurencyjność różnych poziomów/jednostek systemu gospodarczego. Przegląd powinien zostać dokonany w układzie poziomów systemu gospodarczego, wychodząc od szczebla mikro, poprzez mezo, aż do szczebla makroekonomicznego. Biorąc jednak pod uwagę chronologię pojawiania się poszczególnych koncepcji teoretycznych, kolejność tę należy albo całkowicie odwrócić albo co najmniej zmodyfikować i zaczaćc przegląd od teorii makroekonomicznych.

Teorie makroekonomiczne, takie jak przede wszystkim teoria przewagi komparatywnej (Smith, Ricardo), teoria kosztów realnych (Taussig, Viner), teoria kosztów alternatywnych (Haberler) oraz teoria względnej obfitości czynników produkcji (Heckscher, Ohlin, Samuelson) nie eksponowały explicite w swoich dociekaniach zagadnień innowacyjności i konkurencyjności ${ }^{7}$, czego skutkiem były problemy z wyjaśnieniem nowych zjawisk i procesów w handlu międzynarodowym, jakie pojawiły się po II wojnie światowej. Główną słabością teorii makroekonomicznych jest abstrahowanie od mikrofundamentów gospodarki i pomijanie obserwowanej w realnym życiu gospodarczym heterogeniczności przedsiębiorstw. Zagadnienia przewagi technologicznej zostały szerzej dostrzeżone dopiero $\mathrm{w}$ teorii luki technologicznej Posnera ${ }^{8}$. W teorii tej podkreśla się, że wiedza i umiejętności technologiczne są dobrem rzadkim oraz że różnice $\mathrm{w}$ poziomie technologii są jedna $\mathrm{z}$ ważnych przyczyn handlu międzynarodowego, a handel z kolei jest kanałem umożliwiającym zmniejsza-

${ }^{7}$ Por. J. Misala, Teorie międzynarodowej wymiany gospodarczej, Warszawa 1990; W.J. Otta, Strategia przedsiębiorstwa na rynkach zagranicznych, w: T. Gołębiowski (red.), Przedsiębiorstwo na rynku międzynarodowym. Analiza strategiczna, Warszawa 1994.

${ }_{8}$ M.V. Posner, International trade and technological change, „Oxford Economic Papers” 13, 1961. 
nie tych różnic, jeśli kraj opóźniony technologicznie potrafi względnie szybko naśladować innowacje kraju przodujaccego. O ile jednak w teorii tej docenia się znaczenie technologii, o tyle nie poświęca się należytej uwagi kanałom jej transferu, redukujacc je do wymiany handlowej oraz przepływów zagranicznych inwestycji bezpośrednich. Nieco podobny charakter ma teoria cyklu życia produktu Vernona ${ }^{9}$, w której zwrócono uwagę na kierunki przepływów handlu i inwestycji pomiędzy krajami znajdującymi się na zróżnicowanych poziomach rozwoju technologicznego w zależności od fazy cyklu życia, w której znajduje się dany produkt. Kluczową rolę odgrywają tutaj kraje przodujące w rozwoju, w których ze względu na wysoki poziom zamożności powstają innowacje, a te następnie podlegają dyfuzji w drodze handlu i zagranicznych inwestycji bezpośrednich. Teoria cyklu życia produktu i jej pochodne koncentrują uwagę na mezoekonomicznym poziomie analizy, gdyż odnoszą się nie tyle do całych gospodarek narodowych czy pojedynczych przedsiębiorstw, ile do branż jako zbiorów przedsiębiorstw wytwarzających podobne produkty.

Jeśli natomiast chodzi o poziom mikroekonomiczny, to kwestia innowacji pojawia się m.in. w tzw. nurcie monopolu ${ }^{10}$, w którym podkreśla się, że pozycja quasi-monopolistyczna przedsiębiorstwa w międzynarodowej współpracy gospodarczej prowadząca do zwiększenia zysków może być m.in. kształtowana przez innowacyjne technologie ${ }^{11}$. W szeroko rozumianym nurcie monopolu mieszczą się także koncepcje strategicznego zachowania się (strategic behavior). Przejawem zachowań strategicznych moga być tzw. inwestycje krzyżowe - lokowanie filii na rynkach macierzystych rywali nie z myśla o realizacji zysków, ale w celu „zabezpieczenia się” przed zaskakującymi posunięciami konkurentów w oligopolu. Wchodzenie na rynki rywali z takich pobudek traktowane bywa jako „wymiana gróźb” ${ }^{2}$. Innym aspektem zachowań strategicznych w oligopolu jest konkurowanie przez postęp techniczny i będące jego wynikiem innowacje. Zgodnie z koncepcja akumulacji technologicznej odniesiona do skali międzynarodowej zaobserwować można tendencję do lokowania inwestycji (w szczególności w sferze badań i rozwoju, a więc potencjalnie generujacych innowacje) w wykształconych ośrodkach innowacji w danej branży. Skutkiem tego jest koncentracja tej działalności w określonych lokalizacjach mających krytyczne znaczenie dla rozwoju innowacyjności w skali międzynarodowej. Zagadnienie dyfuzji innowacji w ujęciu mikroekonomicznym w skali międzynarodowej pojawia się także w tzw. nurcie wydajności ${ }^{13}$. Nurt ten nawiąuje do teorii kosztów transakcyjnych. Koszty transakcyjne przypominaja per analogiam siły tarcia w fizyce odniesione do działalności gospodarczej

${ }^{9}$ R. Vernon, International investment and international trade in the product cycle, „Quarterly Journal of Economics” 80(2), 1966.

10 O.E. Williamson, The Economic Institutions of Capitalism: Firms, Markets, Relational Contracting, New York 1985.

11 S. Hymer, The International Operations of National Firms: A Study of Direct Foreign Investment, Cambridge 1976.

12 E.M. Graham, Intra-industry direct investment, market structure, firm rivalry and technological performance, w: A. Erdilek (ed.), Multinationals as Mutual Invaders: Intra-Industry Direct Foreign Investment, London 1985.

13 W.J. Otta, op. cit., s. 49. 
i obejmują koszty doprowadzenia do transakcji rynkowych oraz koszty nadzoru transakcji rynkowych. Przedsiębiorstwa internalizują działania (wykonuja je wewnątrz swoich struktur), gdy koszt transakcji rynkowej pomiędzy niezależnymi firmami jest wyższy aniżeli koszt międzynarodowego przepływu w ramach struktury przedsiębiorstwa. Innymi słowy, rozwiązania hierarchiczne zastępują rozwiązania rynkowe wtedy, gdy są bardziej efektywne kosztowo, biorąc pod uwagę sumę kosztów produkcji i kosztów transakcyjnych. Przesłanki internalizacji, czyli wykonywania działań w ramach konkretnej firmy albo grupy kapitałowej, do której ona należy, mogą pojawiać się zwłaszcza w przypadku międzynarodowego transferu wiedzy (informacji), a więc w obrocie szeroko rozumianymi wytworami intelektu, gdzie ważne znaczenie odgrywaja prawa autorskie. Wiąże się to z obrotem licencjami (patenty, wzory użytkowe, prawa autorskie, marki i znaki handlowe, sekrety produkcyjne i handlowe, know-how) oraz międzynarodowym transferem reputacji (goodwill). Trudności z patentowaniem wiedzy oraz z ochrona praw patentowych, a także ryzyko naruszenia dobrego imienia moga przemawiać za dokonywaniem transakcji (wykonywaniem działań) w ramach danej struktury kapitałowej (we współpracy matka - córki), a nie przez rynek (sprzedaż licencji czy zawarcie umowy franczyzowej). Analizy makroekonomiczne prowadzone bez uwzględnienia i zrozumienia zarysowanych uwarunkowań mikroekonomicznych narażone sa więc na niebezpieczeństwo powierzchowności albo nawet błędnej interpretacji.

Kolejną koncepcją ujmującą możliwe efekty włączania się firm do międzynarodowej współpracy ekonomicznej jest koncepcja learning by exporting. Jej podbudowę teoretyczną stanowia znane koncepcje „krzywej uczenia się” oraz „uczenia się przez działanie" ${ }^{14}$. Koncepcja ta jest syntezą rozproszonych wątków mikroekonomicznych obecnych explicite lub implicite w następujących obszarach badawczych: teoria organizacyjnego uczenia się, teoria internacjonalizacji, tradycyjna i nowa teoria handlu międzynarodowego, teoria wzrostu gospodarczego oraz nowa teoria handlu międzynarodowego ${ }^{15}$.

Prezentując koncepcję learning by exporting, należy wrócić do jednego z jej filarów, czyli teorii handlu międzynarodowego. Na podkreślenie zasługuje okoliczność, że zależności między eksportem, produktywnością i innowacjami są ujmowane w większości teorii w sposób bardzo zróżnicowany, bazujący na różnych zestawach założeń i bardziej lub mniej zbliżony do rzeczywistości (rynek doskonały, wiedza dobrem publicznym, stałe przychody niezależenie od skali produkcji itp.). W teorii klasycznej (Ricardo) oraz neoklasycznej (Hekscher-Ohlin-Samuelson) abstrahowano od rzeczywistych zachowań firm, w efekcie czego teorie te nie potrafiły wyjaśnić obserwowanych faktów. Z czasem zamiast modeli syntetycznych, uogólnionych w ramach nowej teorii handlu międzynarodowego, zaczęto budować liczne, prostsze modele starające się wyjaśnić

${ }^{14}$ E. Mińska-Struzik, op. cit., s. 39.

${ }^{15}$ Ibidem, s. 39-73. Warto nadmienić, że learning by exporting jest koncepcją stosunkowo nowa, jeśli chodzi o jej względnie samodzielne sformułowanie. Czerpie ona - jak podkreśla Mińska-Struzik - inspirację zarówno z wątków mikroekonomicznych, jak i makro- i mezoekonomicznych. 
konkretne przypadki obserwowane w rzeczywistości ${ }^{16}$. Można więc mówić o wyłanianiu się na płaszczyźnie teoretycznej czegoś w rodzaju rynku wielu modeli aniżeli o dążeniu do zbudowania jednego modelu w sensie Rodrika ${ }^{17}$; m.in. w miare przeobrażeń teorii nastapiło odejście od nierealistycznych założeń o tym, że technologia ma charakter dobra publicznego i że jej dyfuzja jest bezpłatna, kompletna i natychmiastowa ${ }^{18}$. Potem zaczęto uwzględniać wiedzę cichą (tacit knowledge). Niemniej w stosowanych modelach nadal przyjmowano wiele uproszczeń: np. zgodne z obserwacją empiryczną założenie, że innowacje rozprzestrzeniają się stopniowo i nierównomiernie, zostało dostrzeżone w całościowy sposób dość późno przez Vernona ${ }^{19}$.

Szczególnie szkodliwe jest przyjmowanie założenia, że adaptacja technologii do lokalnych warunków pozostaje bezkosztowa i zachodzi automatycznie ${ }^{20}$. Nowa teoria handlu międzynarodowego przyjmuje też założenie przedsiębiorstwa reprezentatywnego, co umożliwia prowadzenie rozumowania w konwencji równowagi ogólnej, z drugiej jednak strony odsuwa się poza obszar dociekań kwestię heterogeniczności firm, która może być źródłem poprawy konkurencyjności. Podsumowując, można stwierdzić, że zarówno tradycyjna, jak i nowa teoria handlu międzynarodowego nie oferuja jednoznacznych i satysfakcjonujących wyjaśnień związków pomiędzy handlem a przyrostem produktywności i w efekcie konkurencyjności.

Poszukiwanie związków pomiędzy współpraca gospodarczą z zagranica a wzrostem innowacyjności i produktywności obecne jest także w modelach wzrostu. W szczególności w modelach wzrostu endogenicznego odbywa się to na przykład przez uwzględnianie efektów akumulacji doświadczenia w postaci uczenia się przez działanie, co jednak zależy od tego, w eksporcie jakich dóbr dany kraj się specjalizuje ${ }^{21}$. W innych modelach wprowadza się innowacyjne dobra pośrednie oraz wzrost jakości półproduktów (Grossman, Helpman), a także opracowanie nowych typów dóbr kapitałowych wskutek prowadzenia prac badawczo-rozwojowych (Rivera-Batiz, Romer) ${ }^{22}$. Modele wzrostu endogenicznego mają charakter komplementarny w stosunku do teorii handlu międzynarodowego, która zakładała egzogeniczny charakter różnic w zakresie technologii wytwarzania. Ograniczeniem tej teorii jest jednak założenie przedsiębiorstwa reprezentatywnego, równoznaczne z homogenicznością przedsiębiorstw.

Należy wreszcie wspomnieć o nowej nowej teorii handlu międzynarodowego, która w punkcie wyjścia przyjmuje mikroekonomiczna perspektywę badawcza, ale pozwala także na określenie makroekonomicznych konsekwencji

16 Ibidem, s. 45.

17 D. Rodrik, Economics Rules: Why Economics Works, When It Fails, and How to Tell the Difference, Oxford 2015.

18 E. Mińska-Struzik, op. cit., s. 44.

19 Ibidem.

${ }^{20}$ Ibidem, s. 46.

21 A. Young, Learning by doing and the dynamic effects of international trade, „Quarterly Journal of Economics" 106(2), 1991.

22 E. Mińska-Struzik, op. cit., s. 49. 
zachowań pojedynczych heterogenicznych przedsiębiorstw angażujących się $\mathrm{w}$ handel. W tym sensie koncepcje nowej nowej teorii handlu międzynarodowego mają charakter uzupełniający i urealniający wcześniej omówione ujęcia. Koncepcje te wywodzą się z pierwotnej propozycji Melitza ${ }^{23}$, która była następnie wielokrotnie rozbudowywana przez tegoż autora, czasami indywidualnie, czasami z innymi badaczami, jak również rozwijana niezależnie przez innych naukowców. Z modelu Melitza i jego pochodnych wynika wniosek, że łączny efekt otwarcia gospodarki będzie tym większy, im więcej przedsiębiorstw podejmie eksport, a najmniej efektywne wycofają się z rynku. Ważną rolę odgrywa tutaj mechanizm autoselekcji, zarówno czystej (naturalnej), jak i świadomej.

Dla pełności obrazu należy jeszcze dodać, że kwestie wpływu współpracy gospodarczej z zagranica na innowacyjność, produktywność i konkurencyjność obecne są także w szerokim zakresie w innych teoriach poziomu mikro, a mianowicie $\mathrm{w}$ koncepcjach organizacyjnego uczenia się oraz teoriach internacjonalizacji firmy. W tym miejscu zostana jednak pominięte.

Generalnie z zawartych w tym punkcie rozważań wynika wniosek, że aczkolwiek w obszarze refleksji teoretycznej nad zależnościami pomiędzy innowacyjnościa, produktywnością/wydajnością i konkurencyjnością a współpraca gospodarczą z zagranicą w minionych dziesięcioleciach intensywnych badań nad tymi zagadnieniami uzyskano niepodważalny postęp, to jednak nadal stan rozpoznania tych ważnych i brzemiennych w skutki związków daleki jest od ideału.

\section{MAPA WYNIKÓW BADAŃ EMPIRYCZNYCH}

Poruszone wyżej zagadnienia związków pomiędzy innowacyjnością, produktywnością i konkurencyjnością a międzynarodową współpraca gospodarczą doczekały się licznych badań empirycznych. Niżej prezentowany przegląd ma charakter wybiórczy i subiektywny. Przedstawione wyniki badań dotyczą gospodarki polskiej.

W badaniach Majewskiej-Bator ${ }^{24}$ podjęto problem wpływu handlu międzynarodowego na zmniejszanie się luki technologicznej. Badania tej autorki wpisują się w schemat analityczny przyjęty w tym opracowaniu. Reprezentantem współpracy gospodarczej z zagranicą w jej badaniach jest eksport, a luka technologiczna, a właściwie jej zmniejszanie, jest zmienną będąca surogatem innowacyjności, przyczyniającej się do wzrostu produktywności/wydajności i w kolejnej instancji zwiększającej konkurencyjność. Zmniejszanie luki technologicznej jest wynikiem m.in. transferu albo dyfuzji wiedzy przez kanały zwiąane ze współpraca gospodarczą z zagranica. W badaniach uwagę skupiono na efektach

${ }^{23}$ M. Melitz, The impact of trade on intra-industry reallocations and aggregate industry productivity, „Econometrica” 71(6), 2003.

${ }^{24}$ M. Majewska-Bator, Rozwój endogenicznej przewagi w handlu międzynarodowym a proces zmniejszania luki technologicznej, Poznań 2010. 
wystawienia się gospodarki danego kraju na rywalizację międzynarodowa, co powinno przyczyniać się do zdolności tego kraju w zakresie absorpcji zasobów wiedzy i budowania egzogenicznej przewagi komparatywnej. Handel jest w tym wypadku kanałem przepływu wiedzy i czynnikiem sprzyjającym uczeniu się. Aby to się stało, dany kraj musi być zdolny do absorpcji wiedzy pochodzacej z krajów wyżej rozwiniętych. Istotnym kanałem przepływu wiedzy jest import dóbr kapitałowych, który jest de facto sposobem przepływu wyników działalności B+R między krajami. Kraj imitator zyskuje w ten sposób możliwość poszerzenia swojej oferty handlowej w drodze uczenia się.

Najważniejsze wnioski uzyskane w badaniach ${ }^{25}$ były następujące:

- istotne znaczenie inwestycji w działalność badawczo-rozwojową i rozmiarów handlu zagranicznego dla zmniejszania rozmiarów luki technologicznej;

- wpływ zagranicznej działalności B+R zawartej w imporcie na zmienne pośrednio wyrażające produktywność uczenia się kraju (PKB per capita, eksport per capita) zwiększa się wraz ze wzrostem jakości kapitału ludzkiego.

Także praca Jakubiak ${ }^{26}$ jest przykładem dość kompleksowego podejścia badawczego wpisującego się w ramy schematu analitycznego przyjętego w tym opracowaniu. Autorka, posługując się koncepcją neoklasycznej teorii wzrostu endogenicznego, zmierzała do ustalenia, w jakim stopniu rozwój gospodarczy w Polsce w latach 1991-2003 mógł być związany z transferem nowoczesnych technologii z zagranicy. W tym miejscu chodzi nie tyle o aktualność badań i uzyskanych wyników, ile o całościowe podejście oraz interpretację jego efektów.

Z badań przywołanej autorki wynikają następujące najważniejsze wnioski:

- Uzyskane w wyniku przeprowadzonych obliczeń wskaźniki technologii zawartej w imporcie, a także dostępność wiedzy technologicznej na skutek współpracy z inwestorami zagranicznymi wskazuja, że w badanym okresie miał miejsce transfer wiedzy zarówno przez wzrost technologicznej zawartości importu, jak i przez współpracę z inwestorami zagranicznymi. Należy podkreślić, że towarzyszyło temu duże zróżnicowanie transferu technologii w zależności od rodzaju produkcji.

- Krajowa wiedza technologiczna wywiera pozytywny wpływ na produktywność, a polskie przedsiębiorstwa dysponują zdolnościami wystarczającymi do wykorzystania zagranicznych technologii, czyli są w stanie identyfikować i wykorzystać dostępną wiedzę w celu poprawy produktywności.

- Rozpatrując technologię zawartą w imporcie, stwierdzono zaskakujący brak związku ze wzrostem produktywności. Wyniki sugeruja, że w badanych latach efekty zewnętrzne związane z tzw. importem wiedzy zawartej w sprowadzanych towarach nie występowały.

W nieco mniejszym stopniu w przyjęty tutaj schemat analityczny wpisuja się badania Ciborowskiego ${ }^{27}$. Autor ten w swoich rozważaniach posłużył się

${ }^{25}$ Ibidem, s. 271-306.

${ }^{26}$ M. Jakubiak, Rola wymiany handlowej $i$ bezpośrednich inwestycji zagranicznych $w$ transferze innowacji do Polski, praca doktorska, niepublikowana, Warszawa 2006.

${ }^{27}$ R. Ciborowski, Międzynarodowy transfer technologii a innowacyjność krajów Europy Środkowo-Wschodniej, Białystok 2016. 
metodami modelowania miękkiego, w którym występowały dwie zmienne ukryte:

- TT - zmienna ukryta transfer technologii opisana przez 3 indykatory:

- TT1 - zagraniczne inwestycje bezpośrednie per capita

- TT2 - import dóbr high-tech jako \% importu ogółem $\mathrm{B}+\mathrm{R}$

- TT3 - międzynarodowy bilans technologiczny jako \% wydatków na

- INN - zmienna ukryta poziom innowacyjności opisana przez 4 indykatory

- INN1 - wydatki na B+R jako \% PKB

- INN2 - wydatki przedsiębiorstw sektora high-tech na B+R jako \% PKB

- INN3 - liczba patentów na 1 mln mieszkańców

- INN4 - eksport high-tech jako \% eksportu ogółem.

Ciborowski ${ }^{28}$ wyprowadził z przeprowadzonych analiz następujące wnioski:

- Polska w latach brzegowych badanego okresu (2004-2013) osiagnęła słabe wyniki, jeśli chodzi o międzynarodowy transfer technologii, jednak uzyskała dla całego okresu najlepsze wyniki na tle takich krajów, jak Czechy, Estonia, Litwa, Łotwa, Słowacja i Węgry. Było to związane z szerokim wykorzystaniem importowanych rozwiązań przez przedsiębiorstwa i efektywnościa ich wdrażania. Polskie firmy wyróżniały się uzyskiwaniem wysokiej produktywności adaptowanych technologii i niejednokrotnie przekształcaniem ich. Niestety sukcesy w zakresie transferu technologii nie przekładały się automatycznie na pozycję innowacyjną Polski.

- W latach brzegowych badanego okresu Polska osiagnęła słabe wyniki w rankingu ze względu na poziom innowacyjności (odpowiednio 7 i 5 miejsce), wypadła jednak nieźle w zestawieniu za cały okres - zajęła 3 miejsce za Czechami i Estonia.

Mińska-Struzik ${ }^{29}$ dokonała przeglądu bogatej literatury na temat badań nad uczeniem się przez eksport przeprowadzonych w ramach wywiadów bezpośrednich w celowo dobranych przedsiębiorstwach w krajach rozwijających się. Autorzy badań dochodzili do wspólnego rozszerzającego wniosku, że kontakty z rynkami zagranicznymi przyczyniają się do wzrostu produktywności $\mathrm{w}$ badanych krajach. Ta sama autorka odnotowała także istnienie nurtu badań wykorzystującego studia przypadku eksplorujące związek między eksportem a działalnością innowacyjna, konstatując, że badania te potwierdzają zróżnicowany przebieg i rezultat uczenia się dostawców w globalnych łańcuchach wartości w zależności od tego, jak są one zarządzane. Trzeci nurt badań stanowią z kolei studia ilościowe wykorzystujace zaawansowane techniki ekonometryczne i duże bazy danych panelowych obejmujacych nawet do kilku tysięcy firm (jednostek produkcyjnych). Większość badań z tego nurtu potwierdza występowanie mechanizmu tzw. autoselekcji, czyli relatywnie wyższych parametrów ekonomiczno-finansowych przedsiębiorstw podejmujacych transakcje eksportowe. Oznacza to, zgodnie ze wskazaniami nowej teorii handlu międzynarodowego, że przedsiębiorstwa decydujące się na ekspansję

${ }^{28}$ Ibidem, s. 252-253.

${ }^{29}$ E. Mińska-Struzik, op. cit., s. 80. 
zagraniczną wykazują wyższą produktywność od konkurentów, którzy takiej decyzji nie podejmują. Z drugiej jednak strony przyczynowość wiodącą od eksportu do podnoszenia produktywności, a więc mechanizm uczenia się przez eksport udało się udowodnić w znacznie mniejszej liczbie studiów empirycznych. Podsumowując liczne nurty badań, Mińska-Struzik ${ }^{30}$ skonstatowała, że uczenie się przez eksport nie jest mechanizmem automatycznym, liniowym i dajacym się ujaćc w prosty schemat. Autorka przeprowadziła także badania empiryczne wśród przedsiębiorstw polskich. W efekcie tych badań zweryfikowano następujące hipotezy:

- Pomiędzy polskimi przedsiębiorstwami przemysłu przetwórczego o różnym poziomie zaawansowania techniki istnieją różnice $\mathrm{w}$ zakresie znaczenia eksportu w procesie wprowadzania innowacji - hipoteza potwierdzona.

- Prowadzenie eksportu w określonych warunkach stymuluje przedsiębiorstwa wysokiej techniki do wprowadzania innowacji i zwiększania produktywności - hipoteza potwierdzona.

- Uczenie rozpoczyna się wraz z wejściem w interakcje z podmiotami rynku zagranicznego - hipoteza niepotwierdzona.

Ogólnie badania omawianej autorki doprowadziły do ważnej konstatacji, że zwiększenie skali i zakresu umiędzynarodowienia sprzedaży przedsiębiorstwa sprzyja jego uczeniu się, a w ostatecznym rezultacie zwiększaniu produktywności.

Kolejnym przejawem współpracy gospodarczej z zagranicą są zagraniczne inwestycje bezpośrednie (ZIB). Wojciechowski ${ }^{31}$ zauważa, że ZIB moga wpływać pozytywnie na produktywność zarówno w sposób bezpośredni, jak i pośredni. Ten pierwszy jest dość oczywisty (nowoczesne linie produkcyjne, nowoczesne technologie produkcyjne, zaawansowana technologia zarzadzania itp.), natomiast w wypadku tego drugiego pozytywny wpływ ZIB na produktywność może być związany z ponoszeniem nakładów na $\mathrm{B}+\mathrm{R}$ implikujących wzrost innowacyjności. Autor ten przyjął w przeprowadzonych badaniach empirycznych, że efekty oddziaływania ZIB na produkcję lub wydajność pracy w kraju goszczącym są zmienne (zarówno w czasie, jak i sile oraz kierunku oddziaływania), uzależnione od specyfiki kraju goszczącego, luki technologicznej oraz czynników o charakterze instytucjonalnym. Badania Wojciechowskiego ${ }^{32}$ doprowadziły do potwierdzenia m.in. następujących hipotez:

- Zależność między obecnością kapitału zagranicznego w formie ZIB a produktywnością w kraju goszczącym ma charakter relacji sprzężonej.

- Wzrost zaangażowania inwestorów zagranicznych w gospodarce (branży) kraju goszczącego wiąże się ze wzrostem produktywności w tej gospodarce (branży).

- Akumulacja ZIB w gospodarce (branży) kraju goszczącego wiąże się z redukcją luki technologicznej.

30 Ibidem, s. 86 i 111-116.

31 L. Wojciechowski, op. cit., s. 131.

32 Ibidem, s. 216-217. 
- Wraz ze spadkiem luki produktywności rośnie implikowana obecnościa ZIB efektywność gospodarowania zasobami w gospodarce (branży) kraju goszczącego.

Weryfikacja powyższych hipotez cząstkowych doprowadziła tego autora do ogólnej konkluzji, że efekty obecności ZIB dla gospodarki kraju goszczącego są zróżnicowane w ujęciu branżowym, w czasie oraz uzależnione od zdolności absorpcyjnych gospodarki wyrażonych luką technologiczna. Wnioski Wojciechowskiego są tym ważniejsze, że zostały sformułowane na podstawie badań obejmujących nie tylko Polskę, ale wszystkie kraje Grupy Wyszehradzkiej.

W badaniach Instytutu Gospodarki Światowej SGH stwierdzono, ,że istnieje pozytywna zależność pomiędzy udziałem nakładów na prace badawczo-rozwojowe w nakładach na działalność innowacyjną a przychodami ze sprzedaży nowych lub istotnie ulepszonych produktów oraz że prowadzenie działalności innowacyjnej w formie prac badawczo-rozwojowych wpływa na udział przychodów ze sprzedaży nowych lub istotnie ulepszonych produktów" ${ }^{33}$. W szczególności zaobserwowano zmniejszanie się luki dzielącej Polskę od bardziej rozwiniętych krajów UE - wskazują na to dane obrazujące intensywność prac $\mathrm{B}+\mathrm{R}$, także w sektorze przedsiębiorstw, ich efekty wyrażone liczbą patentów i wskaźniki odnoszące się do zasobów ludzkich w działalności badawczo-rozwojowej, poprawa udziału wyrobów wysokiej techniki w polskim eksporcie. $\mathrm{W}$ innym rozdziale przytaczanego raportu zawarto jednak mniej pozytywne oceny: „Przeprowadzona w tym rozdziale analiza umiędzynarodowienia narodowego systemu innowacji Polski wykazała, iż pod względem kształtowania się wskaźników internacjonalizacji NSI Polska pozostaje w tyle za większością państw członkowskich UE, w tym także tych z Europy Środkowo-Wschodniej. Polski system innowacji trudno uznać za otwarty na współpracę z partnerami zagranicznymi, co więcej, w okresie 2010-2015 nie zaobserwowano zasadniczych zmian w tym zakresie" ${ }^{44}$. W jeszcze innym rozdziale omawianego raportu na podstawie rozległych badań empirycznych sformułowano generalny wniosek o utrzymującym się znaczeniu przewagi kosztowej w strategiach konkurowania przedsiębiorstw dzięki innowacjom procesowym, mimo dążenia do zwiększenia roli przewagi z tytułu dyferencjacji w efekcie innowacji produktowych i marketingowych. W szczególności odnotowano także niewielki wpływ innowacji produktowo-marketingowych na intensywność eksportu ${ }^{35}$.

Jeśli chodzi o syntezę powyższych wniosków, to należy podkreślić, że mapa wyników badań empirycznych nie daje jednoznacznych wskazań odnośnie do zależności przyczynowo-skutkowych. Związki pomiędzy rozważanymi tutaj czynnikami są niejednoznaczne, cechują się silnymi uwarunkowaniami kontekstualnymi, gdzie dużą rolę odgrywają takie zmienne, jak: czas, doświadcze-

${ }^{33}$ M. Mackiewicz, Nauka, technika i innowacje jako czynniki konkurencyjności polskiej gospodarki, w: M. Weresa (red.), Polska. Raport o konkurencyjności 2017. Umiędzynarodowienie polskiej gospodarki a pozycja konkurencyjna, Warszawa 2017, s. 178.

${ }^{34}$ M. Weresa, Umiędzynarodowienie narodowego systemu innowacji $w$ Polsce, w: ibidem, s. 213 .

35 T. Gołębiowski, M. Lewandowska, Innowacyjność, kooperacja a internacjonalizacja. Wyniki badań dla polskich przedsiębiorstw przemysłowych, w: ibidem, s. 247. 
nie, miejsce prowadzenia działalności, rodzaj prowadzonej działalności itp. Zidentyfikowane mechanizmy nie są dookreślone i trudno jest budować wnioski uniwersalne. W efekcie relatywnie słabe rozpoznanie tych zależności nakazuje powściagliwość i ostrożność w formułowaniu rekomendacji praktycznych, czyli zaleceń kierowanych pod adresem polityki gospodarczej czy strategii przedsiębiorstw, działań samorządu gospodarczego itp.

\section{MAPA REKOMENDACJI DLA POLITYKI GOSPODARCZEJ}

Podobnie jak w wypadku zrelacjonowanych badań empirycznych, przegląd rekomendacji dla polityki gospodarczej będzie miał charakter subiektywny i wybiórczy. Najpierw zaprezentowane zostaną wnioski praktyczne wynikające z omówionych badań empirycznych, a potem zostanie przedstawiony autorski katalog zaleceń dla praktyki gospodarczej. Przed tym jednak warto zajać stanowisko w sprawie ogólnego charakteru czy pryncypiów polityki gospodarczej prowadzonej przez państwo. Na temat krytyki podejścia neoliberalnego napisano już tak dużo, że w tym miejscu wątek ten nie będzie szerzej rozwijany $^{36}$.

Większość stanowisk w kwestii pożądanego kształtu polityki gospodarczej we współczesnym otoczeniu międzynarodowym w warunkach globalizacji i tendencji do pojawiania się kryzysów została więc w konsekwencji wypracowana w opozycji do podejścia neoliberalnego. W tym miejscu ograniczymy się do wymienia najważniejszych z tych stanowisk ${ }^{37}$ :

- Osiatyński ${ }^{38}$ uważa, że pożądana polityka gospodarcza powinna być osadzona w ekonomii post-Kalecki i post-Keynes oraz oparta na dwóch filarach: 1) aktywne uzupełnianie popytu sektora prywatnego wydatkami publicznymi finansowanymi przez wzrost długu publicznego (przy przestrzeganiu ograniczeń wynikających z globalizacji); 2) przywrócenie „partycypacyjnego” modelu wzrostu oraz odwrócenie narastających od lat tendencji polaryzacji rozkładu dochodów gospodarstw domowych.

- Kołodko ${ }^{39}$ zainicjował koncepcję ekonomii normatywnej i normatywnej polityki gospodarczej określanej jako nowy pragmatyzm. Należy podkreślić, że idea nowego pragmatyzmu pojawiła się na kanwie krytyki podejścia neoliberalnego, podejmowanej przez Kołodkę w większości jego prac. Nowy pragmatyzm ma być synonimem zdrowego rozsądku i choćby dlatego zasługuje na po-

${ }^{36}$ Bardzo dobry, syntetyczny przegląd literatury na ten temat prezentuje publikacja: J. Osiatyński, Quo vadis euro - Unio? Perspektywa ekonomii postkeynesowskiej, „Ekonomista” 2016, nr 3, s. 294 .

${ }^{37} \mathrm{~W}$ tym miejscu wykorzystano fragmenty pracy M. Gorynia, Nauki ekonomiczne wobec globalnych i regionalnych wyzwań drugiej połowy XXI wieku, w: C. Zając (red.), Nauki ekonomiczne w XXI wieku-dylematy, wyzwania, perspektywy, Wrocław 2017, s. 17-20.

38 J. Osiatyński, op. cit., 294-295.

39 W.G. Kołodko, Wędrujacy świat, Warszawa 2008; idem, Świat na wyciagnięcie myśli, Warszawa 2010; idem, Dokad zmierza świat. Ekonomia polityczna przyszłości, Warszawa 2013; idem, Nowy Pragmatyzm, czyli ekonomia i polityka dla przyszłości, „Ekonomista” 2014, nr 2, s. $162-179$. 
zytywną konotację. Nowy pragmatyzm cechuje elastyczność, adoktrynalność, realizm i liczenie się z rzeczywistościa, zdrowy rozsądek, podejście mieszane, uwarunkowane kontekstem, a nie demagogia, dogmatami i uprzedzeniami. Niektórzy zgłaszają jednak zastrzeżenia wskazujące, że jest to koncepcja niedopracowana i niejednolita koncepcyjnie, nazbyt eklektyczna ${ }^{40}$.

- New Global Governance (NGG) ${ }^{41}$ to koncepcja stworzona na bazie krytyki tzw. konsensusu waszyngtońskiego (KW), który można określić jako reakcję na wiodąca rolę państwa w procesach industrializacji oraz substytucji importu i oznaczająca zaniechanie/ograniczenie tej roli ${ }^{42}$. Konsensus waszyngtoński był uosobieniem wykorzystania koncepcji ekonomii neoliberalnej do kształtowania polityki gospodarczej. Najkrócej opisuja go trzy pojęcia - liberalizacja, prywatyzacja i stabilizacja makroekonomiczna wiązana ze stabilnością cen. Koncepcja NGG akcentuje różnorodność warunków rozwojowych poszczególnych państw i związana z tym niezasadność traktowania wszystkich przypadków według tych samych reguł wynikających z podejścia neoliberalnego. Nie ma gotowych uniwersalnych rozwiązań pasujacych do wszystkich sytuacji, a każdy przypadek winien być indywidualnie diagnozowany i analizowany ${ }^{43}$. Podkreśla się także konieczność przebudowy architektury międzynarodowej współpracy gospodarczej oraz doprowadzenie do równowagi globalizacji politycznej i globalizacji w znaczeniu gospodarczym ${ }^{44}$.

- Niezadowalające postępy wzrostu i rozwoju gospodarczego w niektórych krajach (zwłaszcza mniej rozwiniętych, doganiających) doprowadziły do wypracowania podstaw nowej polityki przemysłowej (new industrial policy), mającej przez interwencję państwa stymulować wzrost gospodarczy. Istota tej koncepcji jest założenie możliwości pokonania słabości tradycyjnej polityki przemysłowej przez strategiczna koordynację działań państwa i firm ${ }^{45}$. Koncepcja ta wiąże się w pewnym sensie z propozycja New Global Governance. Wypada zwrócić uwagę na dwie cezury czasowe - o ile lata świetności pierwotnej koncepcji polityki przemysłowej przypadały na okres przed KW, o tyle powstanie nowej polityki przemysłowej należy wiązać z niezadowalajacymi rezultatami polityk rozwojowych prowadzonych zgodnie z zaleceniami tego konsensusu. Warto wreszcie wspomnieć o powracajacej debacie dotyczącej market failure i policy failure w kontekście przyspieszonych procesów rozwoju zachodzących w krajach doganiających, w tym w Chinach, i o roli państwa $\mathrm{w}$ kreowaniu struktury gospodarki ${ }^{46}$.

${ }^{40}$ M. Gorynia, Nowy pragmatyzm. Jak jest z nim naprawdę?, „Rzeczpospolita” z 22 lutego 2017.

${ }^{41}$ N. Serra, J.E. Stiglitz (eds.), The Washington Consensus Reconsidered. Towards a New Global Governance, Oxford 2016.

${ }^{42}$ J. Williamson, What Washington means by policy reform, w: idem (ed.), Latin American Adjustment: How Much Has Happened?, Washington 1990.

${ }^{43}$ Zob. D. Rodrik, A practical approach to formulating growth strategies, w: N. Serra, J.E. Stiglitz (eds.), op. cit.; D. Rodrik, Industrial policy: don't ask why, ask how, „Middle East Development Journal" 1(1), 2008, s. 1-29.

${ }_{44}$ J.E. Stiglitz, The Future of Global Governance, w: N. Serra, J.E. Stiglitz, op. cit.

${ }^{45}$ D. Rodrik, Normalizing Industrial Policy, Cambridge 2007.

${ }^{46}$ J. Lin, H.J. Chang, Should industrial policy in developing countries conform to comparative advantage or defy it? A debate between Justin Lin and Ha-Joon Chang, „Development Policy 
- Trzeba jeszcze zwrócić uwagę na polską odmianę polityki gospodarczej z wykorzystaniem rozbudowanych elementów polityki przemysłowej leżąca u podstaw Strategii na rzecz Odpowiedzialnego Rozwoju, firmowanej przez wicepremiera, a obecnie premiera Mateusza Morawieckiego ${ }^{47}$. W analizach tej koncepcji podkreślany jest jej rozmach oraz to, że jest ona odpowiedzią na obserwowane w wielu krajach doganiających tendencje do aktywnego włączania się państwa w aktywizowanie procesów rozwojowych. Jej krytycy podkreślają natomiast duże ryzyko makroekonomiczne, niekiedy nawet woluntaryzm, a także przecenianie pożytków z aktywnej roli państwa w kreowaniu procesów rozwojowych, w tym polityki przemysłowej.

- Ponadto należy wspomnieć o rodzących się albo raczej odradzających się w niektórych krajach postulatach dotyczących prowadzenia protekcjonistycznej, populistycznej, przesyconej nacjonalizmem ekonomicznym polityki gospodarczej $^{48}$. Zauważalna jest tendencja do promowania rozwiązań przeciwnych procesom liberalizacji, globalizacji, ograniczajacych zakres współpracy międzynarodowej i oznaczających de facto zmniejszanie korzyści wynoszonych z międzynarodowego podziału pracy. Trudno jest dzisiaj ocenić, czy tendencja ta będzie miała charakter trwały czy będzie tylko krótkookresowym epizodem.

Zasygnalizowane koncepcje polityki gospodarczej maja charakter zasadniczo dość ogólny, mogący stanowić podkład, ogólne tło, bardziej lub mniej sprzyjające innowacyjności, produktywności i konkurencyjności. Wspólną cechą większości opracowań na temat powiązań współpracy gospodarczej z zagranica z innowacyjnościa, produktywnością i konkurencyjnością jest abstrahowanie od ogólnego kontekstu polityki gospodarczej i koncentrowanie się na wyrwanych z kontekstu ogólnego inicjatywach czy rozwiązaniach. Innymi słowy, formułowane propozycje mają często charakter fragmentaryczny i raczej wyizolowany oraz nie są odpowiednio rozbudowane i uszczegółowione, nie sa więc tym samym całościowe.

Majewska-Bator ${ }^{49}$ wyprowadza $\mathrm{z}$ wcześniej zrelacjonowanych badań wniosek, że „[...] w Polsce potrzebne są działania nastawione na poprawę struktury kapitału ludzkiego zgodnie z potrzebami rozwoju gospodarczego danego kraju, co zwiększy między innymi efektywność uczenia się producentów krajowych od reszty świata". Drugim ważnym zaleceniem praktycznym, wynikającym z badań tej autorki jest wskazanie na uzasadnienie rozwijania handlu przede wszystkim z partnerami z krajów na wyższym poziomie rozwoju technologicznego.

Na podstawie przeprowadzonych badań Jakubiak ${ }^{50}$ sformułowała następujące konkluzje dla polityki gospodarczej:

Review” 27(5), 2009, s. 483-502; China's industrial policy plan v market, „The Economist” 2016, November, 5 .

${ }_{47}$ Zob. Strategia na rzecz Odpowiedzialnego Rozwoju, Ministerstwo Rozwoju, 2017, <https:// www.mr.gov.pl/media/35716/SOR_2017_maly_internet03_2017.pdf> [dostęp: 15.06.2018].

${ }^{48}$ A. Koźmiński, Nowy pragmatyzm kontra nowy nacjonalizm, „Rzeczpospolita” nr 27 (2 lutego 2017).

${ }^{49}$ M. Majewska-Bator, op. cit., s. 316.

${ }^{50}$ M. Jakubiak, op. cit., s. 146. 
- jeżeli państwo pragnie promować rozwój technologiczny krajowego przemysłu, powinno wspierać wybrane rodzaje aktywności zwiększające możliwości absorpcyjne przedsiębiorstw: edukację, badania na potrzeby produkcji, współpracę z technologicznie zaawansowanymi firmami zagranicznymi i zapleczem naukowym oraz - być może w przypadku małych firm - inwestycje w badania i rozwój na potrzeby produkcji;

- z kolei zachęty oferowane dużym, tzw. strategicznym inwestorom, powinny być dokładnie przemyślane.

Ciborowski ${ }^{51}$ formułuje ogólną konkluzję, że kraje Europy Środkowo-Wschodniej przez tworzenie sprzyjających warunków rozwoju technologicznego za sprawą dużych wydatków na badania i rozwój, kształtowanie infrastruktury formalnoprawnej i odpowiedniej polityki państwa jednocześnie mogą sprzyjać uwarunkowaniom mikro- i makrogospodarczym pozwalającym na podnoszenie innowacyjności w długim okresie.

Według Mińskiej-Struzik ${ }^{52}$ celem polityki gospodarczej powinno być stymulowanie przedsiębiorstw do podejmowania i rozszerzania działalności eksportowej, wchodzenia na nowe rynki itp., gdyż tego rodzaju działania moga przyczynić się do zwiększenia innowacyjności tych podmiotów, a w konsekwencji produktywności i konkurencyjności. Środki polityki gospodarczej służące stymulowaniu eksportu mogą równolegle prowadzić do uruchomienia i rozwijania potencjału innowacyjnego - pobudzania i intensyfikacji działalności innowacyjnej oraz wprowadzania nowych rozwiązań technologicznych. Troska polityki gospodarczej powinno być ponadto doprowadzenie do zwiększenia przenikania efektów uczenia się do nieeksporterów.

Wojciechowski ${ }^{53}$ stwierdza, że w związku z ujawnionymi efektami oddziaływania ZIB na innowacyjność, produktywność/wydajność i konkurencyjność przedmiotem uwagi polityki gospodarczej winna być troska o poprawianie zdolności absorpcyjnych gospodarki. Są one bowiem równoznaczne z możliwością uzyskiwania potencjalnych korzyści wynikających z tytułu obecności kapitału zagranicznego przez m.in. dostosowania infrastrukturalne oraz opłacalne z punktu widzenia kraju goszczącego zachęty dla inwestorów (zarówno w branżach zapóźnionych, jak i generujących wysoką wartość dodana).

Podejmując próbę sformułowania rekomendacji dla polityki gospodarczej, sprzyjającej wykorzystaniu związków pomiędzy współpraca gospodarczą z zagranica a innowacyjnościa, produktywnością i konkurencyjnością dla rozwoju gospodarczego, należy podkreślić, że za niewskazane należałoby uznać jakiekolwiek eksperymenty z naruszeniem równowagi w makroekonomicznej polityce gospodarczej czy próby zdecydowanych ingerencji rządu w cechy strukturalne gospodarki ${ }^{54}$. Potrzebna jest raczej pragmatyczna polityka gospodarcza jednocześ-

${ }^{51}$ R. Ciborowski, op. cit., s. 262.

52 E. Mińska-Struzik, op. cit.

${ }^{53}$ L. Wojciechowski, op. cit., s. 222.

${ }^{54} \mathrm{~W}$ tej części opracowania wykorzystano fragmenty dwóch publikacji: M. Gorynia, Polski model konkurencyjności, z Marianem Gorynią rozmawia Jan Gmurczyk, „Instytut Idei” 2013, nr 2; idem, Miejsce gospodarki polskiej w gospodarce Unii Europejskiej w latach 2003-2014, „Przegląd Zachodni” 2016, nr 4. 
nie przywiązująca dużą wagę do równowag makroekonomicznych, zwiększająca poziom dojrzałości niedoskonałych jeszcze instytucji gospodarki rynkowej, poprawiajacca funkcjonowanie rynku pracy, stwarzajaca silne podstawy traktatowe oraz informacyjne dla ekspansji zagranicznej polskich przedsiębiorstw, a także zmierzająca do złagodzenia negatywnych efektów zachodzących procesów demograficznych. Państwo powinno być aktywne w budowaniu konkurencyjności. Co do tego w zasadzie nikt nie ma już dzisiaj wątpliwości. Spory dotyczą sposobu włączania się państwa w rozwój konkurencyjności, czyli roli państwa we współczesnej gospodarce rynkowej. Wydaje się, że rolę tę należy postrzegać jako bardzo ważna, ale jednak ograniczona, jeśli chodzi o zakres ingerencji.

Po pierwsze, państwo powinno budować instytucje, które są niezbędne do działania rynku. Nikt państwa w tej dziedzinie nie wyręczy. Po drugie, państwo jest też odpowiedzialne za działania w sferze infrastruktury, zwłaszcza gdy chodzi o realizację wielkich projektów infrastrukturalnych, gdzie rynek zawodzi. Po trzecie, państwo powinno zapewniać odpowiednią podaż dóbr publicznych, które są niezbędne do zapewnienia określonego poziomu dobrobytu, a których wytworzenie z wykorzystaniem wyłącznie mechanizmu rynkowego napotyka trudności. Po czwarte, szczególnie ważne są działania państwa w sferze zwiększenia zdolności gospodarki do absorpcji wszelkich rodzajów innowacji, nie tylko technicznych. Rola systemu edukacji jest tutaj oczywista.

Jako przykłady bardzo konkretnych obszarów ingerencji państwa można podać rozwijanie skłonności do oszczędzania, gdyż jest to fundamentalny czynnik wzrostu gospodarczego, wspieranie przedsiębiorczości, popieranie konkurencji, zapewnienie prostego systemu opodatkowania, przeciwdziałanie zatorom płatniczym, troskę o bezpieczeństwo obrotu gospodarczego, budowanie i wspieranie systemu informacji gospodarczej, sprzyjanie oszczędności energii oraz ochronę własności intelektualnej.

Wymienione przykłady dają się podporządkować dwom celom. Z jednej strony chodzi o wspomaganie mechanizmów wzrostu gospodarczego i podwyższania konkurencyjności. Z drugiej - należy mieć na uwadze podnoszenie efektywności gospodarowania, co wcale nie wiąże się tylko i wyłącznie z obniżaniem kosztów produkcji, ale dotyczy także tzw. kosztów transakcyjnych, czyli wszelkich kosztów funkcjonowania mechanizmu rynkowego, takich jak poszukiwanie partnerów, negocjowanie kontraktów, rozstrzyganie sporów itp. Z tego ostatniego punktu widzenia szczególne znaczenie ma rozwijanie systemu wiarygodnej informacji gospodarczej, w tym przyjaznej i użytecznej statystyki państwowej.

Najlepszą podstawę budowania konkurencyjności stanowi swoboda prowadzenia działalności gospodarczej, sprzyjająca istnieniu klimatu przedsiębiorczości i innowacyjności, a także występowanie warunków sprzyjających bogaceniu się. Tymczasem pozycja Polski w międzynarodowych rankingach wolności gospodarczej nie jest dobra. Gdyby była lepsza, Polska przyciagnęłaby więcej inwestorów zagranicznych, bez udziału których przy ograniczonych środkach krajowych trudno będzie o znaczący awans gospodarczy i cywilizacyjny. Bynajmniej nie chodzi tutaj tylko o inwestorów zagranicznych. Wyższy poziom wolności gospodarczej pozwoliłby na wykorzystanie uśpionych pokładów przedsiębiorczości Polaków. Uruchomienie zakumulowanych oszczędno- 
ści i urzeczywistnienie drzemiących w głowach Polaków pomysłów biznesowych wydaje się ważna potencjalną dźwignią poprawy konkurencyjności. Od tego będzie zależeć przyszłość gospodarcza i cywilizacyjna Polski.

Cieszy ekspansja polskich firm, wychodzących za granicę w poszukiwaniu nowych rynków zbytu, z myśla o pozyskaniu niedostępnych w kraju zasobów, a także zorientowanych na podwyższanie efektywności. Ale jednocześnie martwi podejmowanie działalności gospodarczej w innych państwach lub jej przenoszenie za granicę, np. w związu z niekorzystnymi regulacjami podatkowymi w Polsce albo innymi ograniczeniami dla prowadzenia biznesu.

Niestety wielokrotnie podejmowane inicjatywy zmierzajace do podwyższenia stopnia swobody prowadzenia działalności gospodarczej kończyły się ograniczonymi sukcesami. Prace w tej dziedzinie powinny być kontynuowane.

\section{ZAKOŃCZENIE}

Na zakończenie należy podkreślić, że związki pomiędzy innowacyjnością, produktywnością i konkurencyjnością a międzynarodową współpracą gospodarczą maja charakter rozbudowany, wielowątkowy i złożony. Nie wszystkie kanały wpływu są dobrze rozpoznane i w sposób adekwatny uwzględniane $\mathrm{w}$ istniejacych teoriach. Podobna diagnoza odnosi się do badań empirycznych - podejmowane próby pomiaru zależności pomiędzy stanowiącymi przedmiot zainteresowania w tym tekście zmiennymi nie dają jednoznacznych wyników. Wobec wyżej wyartykułowanych okoliczności można twierdzić, że mamy do czynienia z niedoskonałą teorią oraz niepozbawionymi wątpliwości wynikami badań empirycznych. W tych warunkach, jak się wydaje, nie ma podstaw do budowania zdecydowanych i bezwarunkowych zaleceń dla polityki gospodarczej.

prof. dr hab. Marian Gorynia

Uniwersytet Ekonomiczny w Poznaniu

m.gorynia@ue.poznan.pl

https://orcid.org/0000-0002-7633-8249

\section{INNOVATIVENESS, PRODUCTIVITY AND COMPETITIVENESS OF THE ECONOMY AND INTERNATIONAL ECONOMIC COOPERATION}

Summary

The main objective of the study is to identify, review and assess the possible relationship between innovation, productivity and competitiveness of the economy and international economic cooperation. The implementation of four specific objectives is subordinated to this purpose. The first goal is to identify and record possible channels of mutual influence between the variables studied. The second goal is to qualify individual channels of influence to various theoretical concepts presented in the literature. The third goal is to review the results of empirical research on the links between innovation, productivity and competitiveness and international economic cooperation, along with their reference to the themes appearing in the literature on the subject. Finally, the fourth goal is to outline the practical implications of the considerations carried out and to present a set of recommendations for economic policy. 